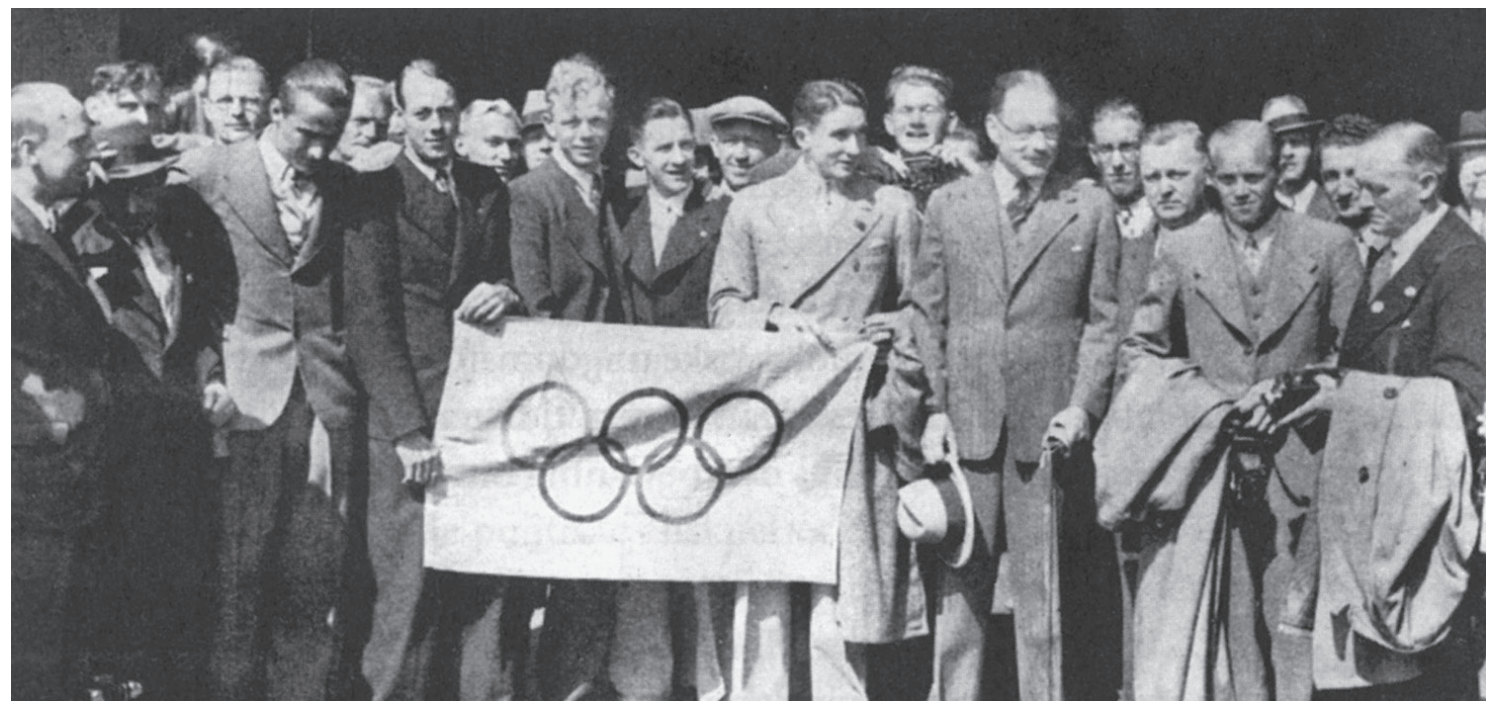

Atletikfolkene blev fulgt på vej af den tyske gesandt Renthe-Fink (th. for flaget med hat i hånden) (Dansk sport i billeder og ord, 1946, s.355).

\title{
Dansk idraet og den nazistiske udfordring i 1930'erne
}

»jeg er i dag efter seks års arbejde i stand til ... at sammensæette et så stærkt mandskab som ønsket og efter ønske fra rigsudenrigsministeren og ikke mindst Føreren selv at sende det til et hvilket som helst sted i udlandet, hvor man ønsker en politisk gevinst«.

(Teichler, 1991, s. 367). ${ }^{1}$ 


\section{INDLEDNING}

Denne artikel forsøger at demonstrere det uadskillelige forhold mellem sport og politik. Efter den nazistiske magtovertagelse i 1933 videreførte og udvidede de vestlige demokratier samkvemmet med Tyskland på sportens område. Det fortsatte samkvem gav det nazistiske regime - i langt højere grad end særtilfældet OL - »et skin af normalitet og kontinuitet «. „Pragmatisme og opportunisme gjorde, at den internationale sport ikke så nogen grund til at indskrænke eller afbryde samkvemmet med den ensrettede tyske sport med anledning i den med statslig terror og åben vold ledsagede omvæltning i Tyskland «. ${ }^{2}$ Danmark var ingen undtagelse fra denne linje. Tværtimod var den dominerende holdning ikke mindst blandt 1930'ernes radikale/socialdemokratiske regeringer, at det tjente Danmarks interesser bedst at undgå at provokere den stadigt mere mægtige nabo mod syd.

Den britiske idræts- og socialhistoriker J.A. Mangan har opregnet tre forbindelser, hvor idræt indgår som et middel til fællesskabsfølelse: 1) ved national solidaritet, 2) ved international konfrontation og 3) ved internationalt samarbejde og forståelse (Mangan, 1995, s.1). Som det vil vise sig, udfoldede dansk idræt sig $\mathrm{i}$ 1930'erne særlig på det tredje område. Hvor der i Danmark internt var konfrontation mellem højre- og venstrefløjen, var samarbejdet eksternt og i høj grad også med Tyskland præget af harmoni.

Artiklen berører også forholdet mellem idræt og dansk national identitet. Det specielle ved idræt i forhold til andre kulturformer som musik og malerkunst er, at den bygger på følelser af identifikation, spænding om udfaldet og et håb om forløsning, der primært opleves via dramatiske kropslige handlinger. Fra omkring år 1900 og frem er idrætten blevet en central are- na, hvor de enkelte lande kan måle sig med hinanden i stærkt symbolladede konflikter, og hvor dyrkelsen af det nationale gestaltes rituelt (Ehn, 1993). Ved store idrætsbegivenheder rejser mennesker sig under nationalsangen for noget, de føler er større end dem selv.

Sporten analyseres i det følgende som en form for kulturpropaganda ud fra perspektivet i f.eks. Peter Becks studier, herunder ikke mindst hans Scoring for Britain, hvor han viser, at også demokratier tenderer mod at bruge sporten som kulturel og nationalistisk propaganda, om end ikke på en så direkte og instrumentel måde, som det ses i et-partistater (Beck, 1999). I nærværende artikel undersøges både det danske publikums nationale fokus og tyskernes brug af sporten som politisk propaganda. En central hypotese er, at den nationale eufori i sportsdyrkelsen i demokratiske stater i vidt omfang medfører en blindhed over for de totalitære staters uhæmmede kulturpropaganda.

Artiklen fokuserer på den danske idrætsverdens reaktioner på den nazistiske magtovertagelse i 1933 med særligt henblik på OL i Berlin 1936. Vinter-OL i Garmisch Partenkirchen er dog ikke blevet inddraget, da disse lege på grund af danskernes svage position $\mathrm{i}$ vintersportsdisciplinerne ikke fik særlig stor opmærksomhed i Danmark. Hovedspørgsmålene er: I hvilket omfang opnåede OL i Berlin officiel accept i Danmark? Var der modstand mod den danske deltagelse internt i Danmark? Var der modstand blandt de jødiske sportsfolk, og hvordan influerede "jødespørgsmålet « den danske debat? Den nazistiske idræt i almindelighed og De Olympiske Lege i Berlin 1936 i særdeleshed er i høj grad blevet gennemanalyseret (Krüger \& Murray, 2003, s. 28). Det centrale spørgsmål i det følgende bliver derfor: Var der noget specielt ved de danske relationer til den nazistiske 
idræt $\mathrm{i}$ forhold til de andre demokratiske lande ${ }^{3}$ Hvordan reagerede den danske idrætsledelse på 2. verdenskrigs udbrud i sammenligning med idrætsledelsen i de andre nordiske lande?

\section{DEN NAZISTISKE SPORT}

I Weimarperioden havde det tyske nazistparti ingen egentlig sportsafdeling, men Sturm Abteilung (SA) var det nærmeste, partiet kom en sådan, især i perioder, hvor der var mindre brug for aktiv gadekamp. Nazistpartiet og især SA var præget af en "völkisch« tankeverden, hvor ethvert folk skulle udtrykke sin kropskulturelle egenart, men i forbindelse med OL i Amsterdam i 1928 og i Los Angeles i 1932 åbnedes øjnene for de tyske sejres propagandaværdi. Efter den nazistiske magtovertagelse kæmpede SA for maksimal indflydelse på sportens organisering $i$ Det tredje Rige. Når den nazistiske ledelse valgte ikke at give efter for det völkische pres, skyldtes det et valg af en internationalistisk linje,



Olympisk plakat. Et arisk overmenneske med glorie understøttet af militære stridskræfte inkarneret i Brandenburger Tors firspand (King \& McGow, UK).

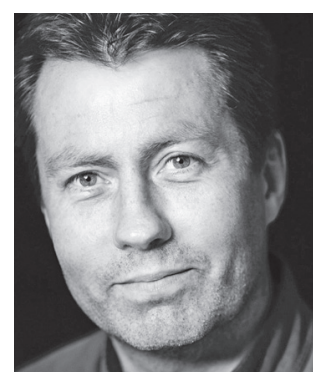

hvor sporten blev brugt som forbindelsesled til og propagandamiddel over for omverdenen. Denne vending blev især effektueret ved Hitlers beslutning af 16. marts 1933 om at fastholde Berlin som arrangør af 1936-legene (Krüger \& Murray, 2003, s. 28).

Personligt var Hitler notorisk ikke-sportsmand. Dog var han begejstret for spektakulære moderne massesportsgrene som boksning og bilvæddeløb. På trods af Hitlers manglende sportsinteresse arrangerede Det tredje Rige de hidtil mest omfattende lege i den olympiske bevægelses historie, hvad angik tilskuertal, presseomtale og økonomiske investeringer. De enorme investeringer var ikke begrundet $i$ veneration for rekordsporten, hvor man i princippet risikerede at tabe til sorte eller jøder, men et udtryk for Det tredje Riges ønske om en blændende æstetisk selvfremstilling og en demonstration af den ariske races og det tyske folks overlegenhed. Hitler var frem for alt optaget af kunst, og den veltrænede ungdom kunne udgøre en perfekt æstetisk kulisse for den nazistiske førerkultus.

Det tyske gymnastikforbund (Deutsche Turnerschaft) var med mere end halvanden million medlemmer det største idrætsforbund for en enkelt idrætsgren i verden (Krüger, 1987, s. 7). Forbundet havde allerede umiddelbart efter magtovertagelsen accepteret den nazistiske ideologi og forsøgte inden Tschammers monopolisering at underlægge sig hele den tyske frivillige 
idræt. Formanden, Edmund Neuendorff, udtrykte klart sin holdning i en herostratisk berømt tale af 1. maj 1933. Heri fastslog han, at Hitler ikke kun kunne "glæde sig over sit Stahlhelm og sit SA, men også over sit tyske gymnastikforbund.« Neuendorff blev dog hurtigt vippet af pinden af Tschammer, som overtog formandskabet og forpurrede gymnastikforbundets stormagtsdrømme. ${ }^{4}$

Som tegn på Det tredje Riges prioritering af idrætten blev Hans von Tschammer und Osten udnævnt til Reichssportführer den 28. april 1933 (Steinhöfer, 1973, s. 146). ${ }^{5}$ Hvorfor udnævntes Tschammer til rigssportsfører på trods af, at han ikke kunne henvise til kvalifikationer inden for idrætsudøvelse eller -ledelse? Ifølge den tyske historiker Hans Joachim Teichler var der to grunde. For det første fordi han gennem sin karriere i SA i 1932-33 havde vist "handlekraft" som ansvarlig for en "SA-gruppe Mitte« i Dessau. Denne terrorgruppe iværksatte den 12. februar 1933 en storm på et kommunistisk partihus i Eisleben. I den bagvedliggende gymnastikhal var en turnering i gang, og angrebet resulterede i 12 arbejdersportsfolks og et 13-årigt barns død samt mange hårdt sårede (Steinhöfer, 1973, s. 24).

Tschammer var i årene efter sin tiltræden i fuld gang med at borteliminere de store socialdemokratiske, kommunistiske og kristne idrætsorganisationer og ensrette hele den frivillige tyske idræt i et stort nazistisk idrætsforbund. Alle de politiske og religiøse idrætsorganisationer blev opløst, mens de politisk neutrale organisationer ikke blev ændret betydeligt, hvis de indvilgede $\mathrm{i}$ at indgå $\mathrm{i}$ den nye paraplyorganisation "Deutscher Reichsbund für Leibesübungen" (DRL). De demokratiske rettigheder blev dog inddraget, og præsidenten - nu kaldet "Führer " - for de enkelte sportsforbund blev udpeget ovenfra. Jøderne blev i 1933 forbudt medlemskab i DRL og blev mere og mere ghettoiseret også inden for sporten (Pfister \& Niewerth, 1999).

\section{SPORT SOM KULTURPROPAGANDA}

Det var en vigtig del af Dansk Idræts-Forbunds (DIF) ideologi, at sport og politik ikke hang sammen. Problemet var blot, at det gjorde det for DIFs tyske samarbejdspartnere - de nazistiske sportsautoriteter. De tyske eliteidrætsfolk blev politiske ambassadører for Det tredje Rige. De blev indskærpet at give et godt indtryk af deres land gennem at »optræde korrekt «, og deres adfærd i udlandet blev overvåget og rapporteret af efterretningsfolk (Teichler, 1991, s. 108).

Den tyske ekspert i nazistisk fodboldhistorie Nils Havemann har peget på, hvordan sporten blev opfattet som et væsentligt politisk middel i Det tredje Rige.

\begin{abstract}
"Rigssportsledelsen, Udenrigsministeriet og Propagandaministeriet betragtede internationale sportsbegivenheder som et middel til at få stater og regioner, der ansås for politisk, militoert eller geostrategisk interessante, trukket storkere ind i den tyske indflydelsessfaere; tysk fodbold såvel som den samlede tyske sport blev set som et glasurlag over den krigeriske ekspansionspolitik, som ved gennemførelsen af stemningsfulde sportsaktiviteter blev forlenet med et harmløst noesten fredfyldt skin " (Havemann, 2005, s. 337).
\end{abstract}

I 1935 besluttede Hitler, at hagekorsflaget skulle vaje ved sportsbegivenheder i stedet for den wilhelminske fane, men med bibeholdelse af de sort-hvid-røde baggrundsfarver for at betone kontinuiteten. Hermed blev et klart politisk symbol ophøjet til nationalsymbol. Et andet til- 


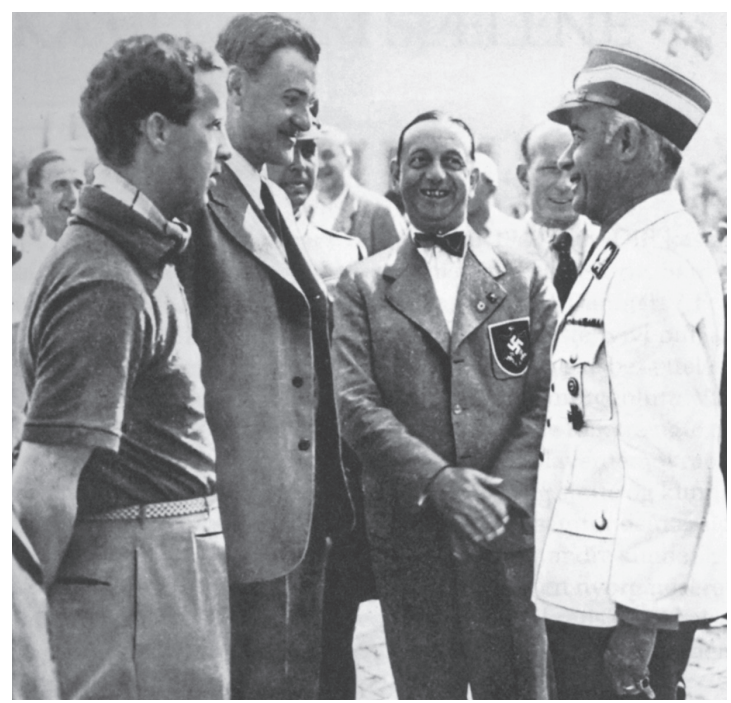

Rigssportsfører Tschammer i uniform i snak med bl.a. Jørgen Beyerholm (den høje herre tv.) Fra etapeløbet Berlin-København 1938 (Beyerholm, 1941, s.251).

tag var, at "Deutschland, Deutschland über alles« med dens fordrende undertone i første linje skulle spilles ved sportsbegivenheder (Teichler, 1991, s. 113f) ofte efterfulgt af den nazistiske slagsang Horst Wessel-sangen ved arrangementer på tysk grund. Da det i øvrigt forventedes, at tyske idrætsudøvere og tilskuere heilede ved afspilning af nationalsangen, var der ingen tvivl om den tyske idræts politisering gennem førerdyrkelsens nazistiske symbolsprog.

Det tydeligste tegn på den nazistiske idræts propagandafunktion var, at der flød langt større midler til repræsentation og propaganda end til selve idrætsaktiviteterne. Den nazistiske idrætspolitik byggede på demonstrative repræsentationsudgifter og en forstærket medieopmærksomhed. Rigssportsfører Tschammer deltog ved hver eneste store internationale idrætsbegivenhed, og spidserne inden for stat og parti viste sig ofte frem ved sportsarrangementer, hvorved Hitlers manglende idrætsinteresse delvist blev udvisket. Selv hvis man ser bort fra byggeudgifterne ved Olympia Stadion og påbegyndelsen af et stadion med plads til 400.000 tilskuere i Nürnberg overgik de repræsentative udgifter ved OL de egentlige sportslige f.eks. gennem genoptagelsen af udgravningerne i Olympia i Grækenland, finansieringen af Leni Riefenstahls Olympia film samt købet af Myrons verdensberømte antikke statue af diskoskasteren.

Pengene fossede til store nationale og internationale idrætsfester og kongresser ofte med stor generøsitet over for tilrejsende idrætsfolk, som f.eks. ved overtagelsen af alle rejseomkostninger for 1200 udenlandske sportsfolk til VinterOL i 1940 på et tidspunkt, hvor der oven i købet var begyndende vareknaphed. Disse lege blev dog aflyst. Idrætsledere blev formfuldendt beværtet og trakteret som vigtige udsendinge fra andre lande. Det er ikke mærkeligt, hvis det kunne være svært for en dansk idrætsudøver eller foreningsleder at modstå en så massiv og bevidst offensiv for at overbevise danskerne om, hvor højt den nye tyske nation værdsatte sporten i almindelighed og Det tredje Riges danske idrætsgæster i særdeleshed (Teichler, 1991, s. 368f).

Den tyske rigssportsfører gjorde meget for at overbevise den danske idræt om det nye tyske styres fortræffelighed. F.eks. var der i 1934 en delegation i Danmark bestående af bl.a.Tschammer selv, gesandt baron von Richthofen, legationsråd Duckwitz, presseattaché Frielitz og Dr. Diem. Tschammer havde "flere gange» før besøgt Danmark og var nu i Danmark for at orientere danske idrætskredse om forberedelserne til De Olympiske Lege. ${ }^{6}$ Rigssportsføreren inviterede Niels Bukh til at give opvisning ved OL i Berlin helt uden om Den Danske Olympiske Ko- 


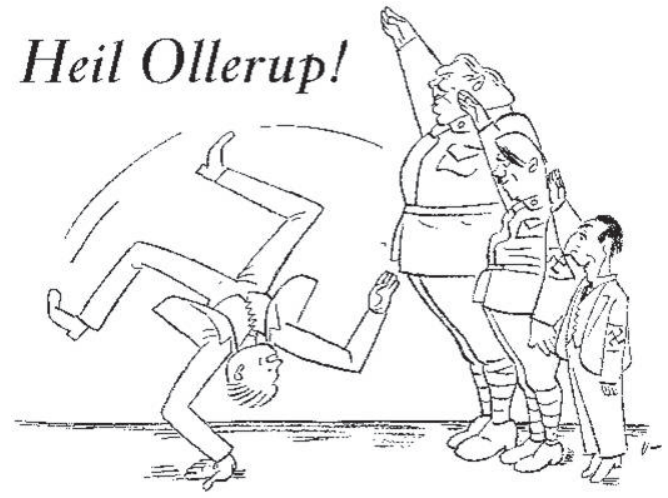

Under Arne Ungermanns karrikatur står bl.a.: »Tag ned til de brune og læg dig på maven, slå kraftspring, slik spyt - selv om pressen bli'r gnaven« (Svikmøllen, maj, 1933).

mité, der først blev taget i ed på et senere tidspunkt.

Til sammenligning gjorde britiske regeringer i mellemkrigstiden meget lidt for at støtte elitesporten i at få international succes. Der blev f.eks. ikke oprettet statsstøttede elitetræningscentre, og der var heller ikke statsstøtte til deltagelse i De Olympiske Lege eller "Empire Games«, skønt ledende britiske politikere godt på selvstændig basis kunne deltage i fundraising. En britisk journalist skrev på denne baggrund efter Vinter-OL i 1936 i Garmisch Partenkirchen, at de britiske skiløbere havde konkurreret mod "statsstøttede gladiator-skiløbere fra de alpine lande« (Huggins \& Williams, 2006, s. 129f).

Heller ikke i Danmark var der i mellemkrigstidens tradition for statsstøtte til DIF. DIF modtog således det uanseelige beløb af 35.000 kr. i 1938. I det hele taget var der langtfra konsensus om idrættens samfundsgavnlige betydning. Særlig var mange kritiske røster vendt mod "rekordjageriet«, og kvinder og børns deltagelse i eliteidræt. Idrætten var i så høj grad under be- skydning, at DIF i oktober 1933 så sig nødsaget til at udgive et forsvarsskrift med titlen: "Dansk Idræts-Forbund og dets kritikere» (Trangbæk, 1995, Bind I, s. $117 \&$ 147ff).

\section{BOYKOT?}

De Olympiske Lege i 1936 var den enkeltbegivenhed, der bragte danskerne tættest på nazisternes satsning på organisation og orden og forsøget på at skabe stærke fællesoplevelser gennem æstetiske masseoptrin. Det centrale danske fagblad inden for idrætten, Idrætsbladet, arbejdede på at fremmane en positiv stemning frem mod sommerlegene og søgte at få så mange danskere som muligt til at rejse til Berlin for at støtte de lovende danske idrætsudøvere. Under overskriften "En fin chance! Hvem vil med til De Olympiske Lege«, skrev bladet:

"Olympiade-feberen or over alverdens ungdom, også over Danmarks. Med skinnende øjne studeres beretningerne om, hvad der skete under vinter-olympiaden, og om det hastigt fremadskridende arbejde med opbyggelsen af den olympiske by og det olympiske stadion $i$ Berlin ... Med stigende beundring har man loest om de bedrifter, som vore egne lovende idrcetsudøvere har udført gennem de senere måneder, Ragnhild Hvegers sejre og rekorder satte forventningerne højere end nogen sinde før tidligere olympiader [...]

Jo der er grund til optimisme. langt de fleste af landets beboere venter med glødende interesse på den dag, da den olympiske ild er nået sin vej fra olympen $i$ Grakenland til det olympiske tårn $i$ Berlin, og legene begynder «. ${ }^{7}$

Roeksperten Axel Lundquist skrev fra Berlin: "Min første gang i morges gik ud til Grünau. Det var storslået, hvad tyskerne i fjor havde lavet 
derude ved Lange See; men i år er det hele sceneri endnu mere imponerende. Særlig den store tribune ude i vandet - med plads til 6000 tilskuere - gør et kolossalt indtryk. Den har kostet 150.000 Reichsmark og skal rives ned igen efter legene, men så har den også betalt sig selv «. ${ }^{8}$

Det var dog ikke alle, der deltog i hyldestkoret op til De Olympiske Lege. Både blandt danske socialdemokrater og i højeste grad kommunister var der indsigelser mod Berlinlegene, hvilket jo ikke kunne undre, da nazisterne havde smadret og forbudt den venstreorienterede idrætsbevægelse. Den venstreorienterede socialdemokratiske idrætsorganisation Dansk Arbejderidræt tog i modsætning til den »borgerlige« idræt og presse kraftigt afstand fra OL. Niels Bukh var en særlig torn i øjet på både den kommunistiske og den socialdemokratiske opinion. Om Tschammers invitation af Bukh til OL ved et besøg på Gymnastikhøjskolen i marts 1935 skrev bladet Arbejder Idræt, at "Der Führer" (Tschammer) havde haft en samtale, der varede syv timer med »den danske overnazist Niels Bukh« (Hansen, 1993, s. 122).

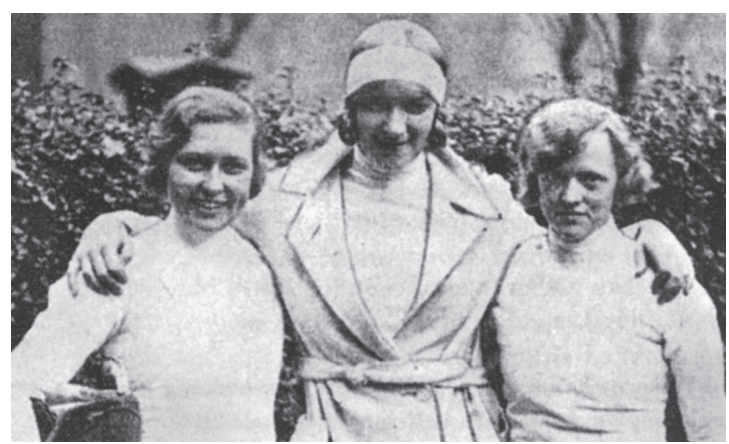

Fægteren Helene Mayer var den eneste jødiske idræetsudøver på det tyske OL-hold. Hun vandt i øvrigt sølv. Her ses hun sammen med danskeren Grete Olsen og fru dr. Munch (Dansk sport, 1946, s.238).
Den jødiske idrætsforening Hakoah, der var tilknyttet Det Mosaiske Troessamfund i Danmark, besluttede sig for at boykotte legene (Thelmark, 1999), og Danmark mistede en stor medaljechance i brydning, da Abraham Kurland fulgte trop i boykotten. De Konservatives absolutte topfigur, John Christmas Møller, løb solo hos de konservative ved at markere sig klart imod legene. I Udenrigsministeriet noterede man sig Christmas Møllers hårde linje allerede ved årsskiftet 1935/36, og der er i ministeriets arkiv bevaret et brev fra Christmas Møller, som klart afdækker hans holdninger til OL. Brevet viser, at den danske gesandt i Berlin Herluf Zahle havde henvendt sig til udenrigsminister Munch i anledning af Christmas Møllers holdninger. Af et brev mærket "Personligt. Fortroligt « fremgik det, at når Christmas Møller ikke offentligt havde givet udtryk for, at Danmark burde undlade at deltage i De Olympiske Lege, skyldtes det, at det kunne han godt se, at det kunne Danmark ikke »lade være med«. Christmas Møller ville imidlertid:

"først og fremmest sige følgende, som jeg synes, det må vare en dansk politikers ret at sige uden at gå nogen berettiget interesse for noer, at det nuvarende Tyskland ved dets knoegten af ytringsfrihed, med dets knogten af forsamlingsfrihed, trykkefrihed, foreningsfrihed, politisk frihed, er så lidt i overensstemmelse med, hvad jeg forstår ved sand og gentlemanlike sportsånd $i$ det daglige liv, at det at afholde De Olympiske Lege $i$ Tyskland jo $i$ virkeligheden er en parodi«.

Zahle gav udtryk for overordnet at være enig i Christmas Møllers synspunkter, men konkluderede alligevel, at Danmark af politiske grunde burde deltage i legene, da Hitler ville opfatte en vægring som en uvenlig gestus. ${ }^{9}$ 
I Danmark udviklede der sig også en protestbevægelse blandt kulturradikale kunstnere, der forsøgte at etablere en boykot mod konkurrencen om sportskunstværker ved OL. I den anledning så det danske IOC-medlem prins Axel sig nødsaget til at forespørge om vilkårene for deltagerne i kunstkonkurrencerne ved OL. Fra præsidenten for Den Tyske Olympiske Komité, Dr. Theodor Lewald, modtog han det forventede svar, at der var fri adgang til at deltage i konkurrencen for alle kunstnere uanset religiøst eller racemæssigt tilhørsforhold. Svaret overbeviste dog ikke de aktionerende kunstnere, som var optaget af den generelle tyske jødepolitik, men danske kunstnere deltog alligevel (Hansen, 1993, s. 122)

Den Danske Olympiske Komité (DOK) afviste, at Berlinlegene ville blive brugt til politisering. Som modsvar mod "kunstnerprotesten«, der blev set som utidig indblanding í idrættens forhold, svarede DOK i punktform, at

1) "De Olympiske Lege har ikke skiftet karakter, fordi de er henlagt til Tyskland. De har intet politisk formål, men kun et idrætsligt og kulturelt«.

2) „Betegnelsen 'Hitler-olympiade' er misvisende og tendentiøs. Legene er af den internationale olympiske komité henlagt til Tyskland, men de tyske arrangører har i enhver henseende den pligt at holde sig legenes regler og ånd efterrettelig og har givet de mest vidtgående løfter herom«.

3) "Mellem dansk og tysk idræt består et fast og venskabeligt samarbejde, som Danmarks idrætsmænd er glade for. Vi har regelmæssige idrætskampe i mange idrætsgrene, $i$ fod- bold, roning, lawn-tennis, brydning, boksning, atletik, ridning, svømning osv. osv. Eftersom vi kun har udbytte og glæde af dette samkvem med Tyskland, ville det være komplet meningsløst at holde os borte fra et verdensstævne, fordi det finder sted i Tyskland, hvor vi altid føler os velkomne, og også denne gang er sikker på at blive behandlet godt «.

4) "Danmarks udeblivelse fra Olympiaden i Berlin vil blive opfattet som en protest og en uvenlig handling mod vore tyske idrætsfæller. Danske idrætsmænd har intet ønske om at lade politiske anskuelser influere på det sportslige samkvem. Skal der fra dansk side protesteres mod visse tyske metoder inden for landets egne grænser, skulle idrætsmændene, der kun har mødt venlighed fra tysk side, være de sidste til at fremkomme med en sådan protest «.

Samtidig med DOKs erklæring fremkom en skrivelse fra Den Internationale Olympiske Komités (IOC) formand, den belgiske grev Henry BailletLatour, til de nationale olympiske komiteer. Ifølge "Jysk Idræts Blad" havde Baillet-Latour foretaget en undersøgelse og haft en samtale med Adolf Hitler, der havde overbevist ham om, at kampagnen for boykot var "politisk, baseret på grundløse erklæringer, hvis falskhed jeg uden vanskelighed har afsløret. « ${ }^{10}$

I toget på vej til OL modtog de svenske OLdeltagere fra antinazistiske landsmænd en konvolut med kort over koncentrationslejre. Det gjorde ikke det store indtryk i den danske presse. Berlingske Tidende fokuserede eksempelvis alene på, hvor farligt det ville have været for OL-deltagerne, hvis det tyske politi havde fundet materialet. ${ }^{11}$ 


\section{DEN DANSKE OPLEVELSE AF LEGENE}

Ved OL i 1936 kunne de tilrejsende danske tilskuere og idrætsfolk opleve »højdepunktet af propagandistisk selvfremstilling " i Det tredje Riges historie (Thamer, 1986, s. 425f). ${ }^{12}$ De nazistiske arrangører havde sat alt ind på at give verden en grandios fest, som skulle få alle spor af forfølgelse og vold til at forsvinde. Atleterne skulle deltage i et OL, hvor pigernes blå øjne og blonde hår vakte genklang hos tyskere, som roste dem for deres ariske udseende, og hvor de mandlige deltagere blev anmodet om at give deres bidrag til en sædbank til udvikling af den nordiske race (Hansen, 1993). ${ }^{13}$

I ugerne op til OL var alle kampagner mod jøder blevet indstillet, og antisemitiske indskrifter på mure og skilte overmalet (Thamer,1986). En gymnastikpige havde under en banket på den danske ambassade i Berlin givet udtryk for, hvor herligt det hele var, hvorefter hendes dansepartner, formentlig en ambassadefunktionær, fortalte hende, at det under OL var blevet tilladt for en arisk mand at rejse sig op for en jødinde f.eks. i en sporvogn, men "kun under olympiaden «. ${ }^{14}$

OL i 1936 blev en fantastisk mulighed for det nazistiske regime til at påvirke en hel generation af unge eliteidrætsfolk og deres ledere. Der var 138 aktive idrætsfolk - 123 mænd og 15 kvinder foruden dommere, sekundanter, ledere og kongresrepræsentanter (Kristensen, 1996, s. 171). Berlinlegene gav kontinuitet i den danske idræts fascination af Det tredje Riges idrætskultur helt ind i besættelsen til omkring 1941/42. Mange af de ledere og idrætsudøvere, der under besættelsen kom til at konkurrere med tyskerne, havde deltaget ved OL i 1936. Blandt de mere prominente atletikfolk kan nævnes atletikfolk som tikæmperen Svend Aage Thomsen og langdistanceløberen Harry Siefert. Blandt bokserne boksetvillingerne Kaj og Viggo Frederiksen, Poul Kops. Hos bryderne Robert Voigt. Det blev ikke til nogen guldmedaljer for det danske OL-hold, men to sølvmedaljer i svømning og roning og tre bronzemedaljer i boksning, military og svømning.

En tyskvenlig leder som baneleder og pressechef i Dansk Bicycle-Club, Jørgen Beyerholm, var med, og rapporterede fra legene. Det samme gjaldt den senere succesfulde danske mellemdistanceløber og journalist på den nazistiske avis Fædrelandet Hans Spanheimer, der entusiastisk berettede fra den internationale ungdomslejr, som tyskerne havde arrangeret med alt betalt for 30 deltagere fra de europæiske lande. Lejrene var bygget af militæret, og al mad blev tilberedt af soldater. På legenes åbningsdag skulle de unge mennesker deltage $\mathrm{i}$ en såre politisk handling: kransnedlæggelse ved den ukendte soldats grav. Der var også arrangeret en international sportsstudenterlejr med ca. 1.000 europæiske deltagere, hvor der bl.a. var udflugt til stævne i svæveflyvning og faldskærmsudspring (Ibid, s. 56-61 \& 80-83).

I begyndelsen var der dog ikke meget at berette om på den front, og i den borgerlige danske presse blev Bukhs opvisning en forløsende begivenhed, ikke mindst fordi der før opvisningen endnu ikke var høstet danske medaljer. ${ }^{15}$ Senere sørgede især svømmepigerne Ragnhild Hveger og Inge Sørensen med deres sølv- og bronzemedaljer for, at Danmark fik del i medaljehøsten, skønt danskerne havde sat næsen op efter guld til den rekordstærke Hveger.

Nazistpartiets hovedorgan Völkischer Beobachter gjorde generelt ikke meget ud af de olympiske gymnastikopvisninger. Hverken nordmændenes eller finnernes blev omtalt, og svenskernes blev der kun ofret nogle få bemærkninger på. Anderledes var det med Danmark. Ud 
over tyskernes fandt avisen »den verdenskendte Niels Bukhs« opvisning værdig til udførligere omtale: Opvisningen blev "gennemført med en forbløffende samtidighed og en ensartethed, der først næsten gav et chok i tilskuerne, inden de brød ud i et hjerteligt bifald «. ${ }^{16}$

På hjemrejsedagen stod et militærorkester med 33 mand parat, som ifølge DDSGIs formand Arnth-Jensen istemte "Kong Christian«, idet gymnasterne viste sig. Med Bukh, Arnth-Jensen og dirigenten i spidsen marcherede gymnasterne gennem Berlins gader «. ${ }^{17}$

\section{OL'S EFTERDØNNINGER}

Legene i 1936 var en sådan succes i Danmark, at Inge Sørensen ved hjemkomsten blev modtaget af 30.000 mennesker ved Enghave Station og Ragnhild Hveger af 10.000 i Helsingør (Idorn, 1971, s. 106). Denne stemning smittede af i de borgerlige aviser og i Idrætsbladet, hvilket tyskerne var opmærksomme på. I den danske udenrigstjeneste havde man fra første færd noteret sig, at de tyske myndigheder tillagde positiv presseomtale af legene stor vægt. Gesandtskabet i Berlin registrerede således, hvor »nøje man fra tysk side overvåger, hvad der i udlandet skrives om olympiaden, og hvor ivrig man er for at bringe hvert anerkendende ord til de tyske læseres kundskab«. Som eksempler vedlagde gesandtskabet udklip fra Berliner Börsen-Zeitung for 8. februar 1936 med »en københavnermeddelelse« om Politikens og Berlingske Tidendes artikler fra Vinter-OL i Garmisch-Partenkirchen. ${ }^{18}$

Goebbels' propagandaministerium fik udarbejdet en rapport om opfattelser af De Olympiske Lege i den udenlandske presse. Hvad Danmark angik, faldt særligt holdningerne til OL hos den "venstreorienterede presse anført af regeringsorganet " Socialdemokraten ministeriet for brystet. Set med nazisternes øjne faldt So-



Dette hyppigt bragte billede er efter befrielsen blevet et ikon på dansk modstand mod den tyske propaganda. Som danskerne så sig selv med tilbagevirkende kraft (Krarup, 1989)

cialdemokraten "tilbage til sin gamle fjendtlige attitude«. Niels Bukh var den eneste danske idrætsleder, som blev citeret. Han behøvede åbenbart ikke nærmere præsentation, for han nævntes blot ved sit navn i et ganske fyldigt referat af nogle udtalelser til Flensborg Avis (Bellers, 1986).

Der var blandt deltagerne ved OL i 1936 i det hele taget kun få mislyde at spore. Inden for kvindeidrætten var der også eksempler på en stærk fascination af det ny Tyskland og "vor tids største sportsstævne«, De Olympiske Lege i Berlin 1936. Ifølge den ene af de to formænd for Dansk Kvinde-Gymnastikforening (DKG) gymnastiklederen Ellen Paul-Petersen, der i øvrigt senere optrådte med hold ved et dansk-tysk gymnastikstævne i februar 1941, havde de kvindelige idrætsdeltagere følt sig godt tilpas i kvindelejren "Friesenhaus" ved Tschammers nye store sportsanlæg "Haus des Deutschen Sports", hvor omgivelserne både inden- og udendørs var »ideelle«. Hun skrev i en illustreret artikel om 
"Den tyske sports hjem - det nye centralpunkt for al tysk legemsopdragelse«, at:

"Som et bevis på den faellesorganisation og forsøg på ensrettethed, som der på alle områder gøres $i$ Tyskland, kan noevnes det nye hjemsted for al legemsopdragelse, oprettelsen af 'Haus des Deutschen Sports', et eksempel som opfordrer til efterligning".

Hun billigede rigssportsførerens arbejde på at skabe et organisatorisk monopol ved at forbyde alternative idrætsforbund i forhold til det nazistiske, og hvor målet var, at Adolf Hitlers ensrettede kropspolitik skulle nå bredt ud i det tyske rige. ${ }^{19}$

Det gjorde ikke fascinationen af tysk idræt mindre, at DKG og bredere dele af den tyske kvindeidræt var inspireret af nye tyske gymnastiksystemer - især Heinrich Medaus - hvilket viste sig ved en stærk interesse i 1936. Medaus' gymnastik byggede på bløde, fjedrende totalbevægelser, hvor alle kropsdelene indgår elastisk i enhver bevægelse, og hvor der øves med rekvisitter som bolde. Med Ellen Paul-Petersens udtryk: "Lad det være sagt straks: Hvor er der dog meget vidunderligt og dejligt naturligt ved den tyske gymnastik «. ${ }^{20}$

DIF reagerede altså ikke kritisk på den tyske idræts ensretning. Tværtimod indgik det brede danske idrætsliv i hyldestkoret ved OL 1936 på trods af, at en DIF-medlemsorganisation som Hakoah måtte føle sig aldeles uvelkommen hos det antisemitiske styre og derfor valgte helt at blive væk.

\section{JENNY KAMMERSGAARD}

I slutningen af 1930'erne var de største danske kvindelige sportsstjerner svømmepigerne. Opmærksomheden samlede sig primært om Ragnhild Hveger, Inge Sørensen og Jenny Kammersgaard, hvoraf sidstnævnte dog ikke var konkurrencesvømmer og således heller ikke deltog ved OL i 1936. Når Kammersgaard nu skal fremhæves, skyldes det, at hun blev det mest prominente eksempel på, hvordan de tyske idrætsautoriteter brugte sporten til at skabe en tiltrækning hos "ariske« udenlandske idrætsstjerner til Det tredje Rige.

Jenny Kammersgaard var født i 1918 og blev i 1934 medlem af Horsens Svømmeklub og Gymnastikforening. Hun udmærkede sig ikke som Ragnhild Hveger ved en iøjnefaldende teknik, men ved stor viljestyrke og udholdenhed. I 1936 gennemførte hun sin første langdistancesvømning gennem Horsens Fjord. De følgende år imponerede hun, både hvad distancer og varighed angik.

Kammersgaard forklarede selv, hvilke psykiske indstillinger der lå bag hendes fænomenale evne til at opholde sig i vandet. Hendes forklaringer minder meget om nutidens mentaltræning og visualisering:

"Jo laengere jeg skal svømme, des mer skal jeg have musklerne strakt ud, så de bliver lange og bløde... Jo mer de strakkes og blødgøres, des mer smidige bliver de, og mens de korte og hårde muskler kroever mange krafter at både hjerte og lunger, så kraever de lange, bløde muskler ingen. At få musklerne til at makke ret og at finde kroppens flydepunkt er hemmeligheden bag distancesvømning. Hvordan man finder den bedste muskelloengde og elasticitet og flydepunktet, så kroppen borer af sig selv, er ikke til at skrive om. Det er bare noget man føler - og på denne store tur indstillede jeg mig på at blive ved i fire døgn«.

I august 1937 svømmede hun på godt 29 timer fra Odden til Sangstrup Klint nord for Grenå. Efter turen tog hun på et sandt triumftog. Første stop var København, hvor hun blev fulgt af et 
optog til Politiken på Rådhuspladsen, hvor redaktør Niels Hasager og Valdemar Koppel var hendes værter. Emil Andersen havde været oppe på Idrætsbladets redaktion, kom ned med en stabel breve og telegrammer:

"Mellem bunken var der et telegram fra Hitler. Der blev stor opstandelse. Min bordfcelle talte om, at det var første gang, at et statsoverhovede havde sendt et telegram til et sportsmenneske fra en fremmed nation. Jeg synes, det var venligt af Hitler. Og minsandten, lidt efter kom Mr. Smile igen med et telegram fra det store Ullstein Forlag med en invitation til Mr. Smile og mig om at komme flyvende til Berlin. Jeg blev vel nok glad. Så tit har jeg ønsket mig at flyve, og nu skulle jeg snart op i luften".

For de tyske nazister var en "nordgermansk" kvindes nærmest overmenneskelige bedrifter i vandet et tegn på den ariske races fuldkommenhed. I telegrammet fra Hitler sendt fra hans sommerbolig i Berchtesgarten stod: "Modtag også mine hjerteligste lykønskninger $i$ anledning af Deres enestående sportslige præstation«.

Som resultat af sin bedrift blev hun umiddelbart efter svømmeturen inviteret til Berlin af det tyske blad "Berliner Illustrierte Zeitung«. Jenny Kammersgaard blev hilst farvel af en del fremmødte danskere, da hun i fly tog afsted sammen med Mr. Smile, der fulgte hende på hele hendes Tysklandsfærd. Allerede på Tempelhof flyvepladsen i Berlin blev hun mødt af mange tilskuere, journalister og pressefotografer, der

"[...] stormede løs på mig. Det gik stcerkt. I løbet af nogle få minutter var jeg fotograferet hundrede gange, havde talt $i$ tysk radio og sagt - på dansk selvfølgelig - tak for telegrammet fra Hitler, og det var dejligt at komme til Berlin. Jeg hilste uafbrudt på folk. Mange danske, der var kommet, råbte Jenny og hurra. Tysker-

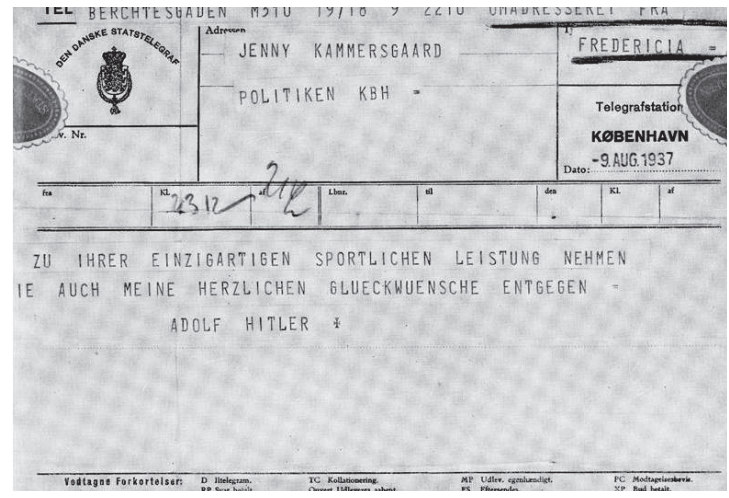

Hitlers telegram til Jenny Kammersgaard (Kammersgaard, 1937)

ne råbte Jenny Kattegat. Lufthansa gav mig en voeldig buket, og Berlins Illustrierte Zeitungs redaktør Utrecht gav mig den allerfineste $i$ danske farver. Mr. Smile var gesvindt til at oversatte, men man virker da så sart trokvorn, når man ikke kan sige det, man vil, til folk«.

Den tyske presse var tydeligvis meget optaget af svømmerens bedrift, for:

"Fra lufthavnen kørte vi i bil til 'Eden Hotel', et sted, hvor filmstjerner og skuespillere holder til. Det var også en overraskelse, at alle aviser, der lå her, var fyldt med billeder og artikler om 'det lille danske vidunder'. Jeg kiggede på mig selv. 140 gode danske pund - men alle kunne kende mig efter billederne... I de mange aviser omkring mig fra verden, der lå her, kunne jeg også se, at Hitlers telegram til mig var kendt over hele jorden. I nogle aviser sad vore billeder sammen, som når folk har sølvbryllup«.

Senere blev Jenny Kammersgaard hentet på sit hotel af rigssportsfører Tschammer, der kom i "[...] sin koempebil, som han selv kørte. Det var en smilende og rask mand. Jeg sad godt nok 
ved siden af ham, men hvad han sagde, kender jeg ikke noget til, men hans smil og øjne var nemt at forstå

Da de kom til Rigssportsakademiet for Legemsøvelser, holdt Tschammer en tale for hende, hvor han hilste fra den tyske fører, der mente, at Kammersgaard med hendes imponerende distancesvømning måtte være en fisk. Det blev herefter aftalt, at tyske videnskabsmænd skulle undersøge det fysiologiske vidunder, hvilket dog først lykkedes en uges tid senere i København. Von Tschammer gav hende et album med "storslåede billeder fra stadion og olympiaden " og andre gaver og forsikrede hende om, at hun for fremtiden altid ville være velkommen i Tyskland, hvilket skulle vise sig ganske relevant.

De "mange tusinde mennesker « på Rigsakademiets svømmestadion ville se Jenny Kammersgaard i vandet, og der blev derfor fremskaffet en badedragt, så hun kunne vise sin svømmeteknik ved kattegatsvømningen. Dernæst var hun til middag på hotel »Eden« og bagefter i det fashionable varietésted Scala. Overalt »kunne folk kende mig og råbte Jenny Kattegat".

Dagen efter fik Kammersgaard invitation af "Rigsminister dr. Goebbels" om at komme til München. Det "var vel nok et storslået tilbud, men det kunne ikke lade sig gøre, da jeg skulle være i Horsens næste formiddag «.

I Horsens blev hun også festligt modtaget: "Aldrig har jeg vidst, at Horsens var så stor en by. Her foran rådhuset var der ikke til at se enden af folkemasserne. Det var ufatteligt, at alle de tusinde mennesker var kommet for at hilse på mig, der plejede at gå her i gaderne som en af de andre sypiger fra Madsens Trikotagefabrik «.

Bogen om "Svømmeturen" var skrevet af forfatteren og journalisten Niels Anesen. Men han ville ikke skrive det sidste kapitel om triumftoget i Tyskland efter turen, måske fordi han ikke delte Jenny Kammersgaards begejstring for Hitler, sportsføreren og det sportsglade Tyskland og derfor ikke havde lyst til at garnere sin historie med fotos af Hitlers telegram og køreturen med Tschammer. Den danske svømmestjerne var stødt over, at Niels Anesen ikke ville tage den sidste del med, men skrev den så i stedet selv (Kammersgaard, 1937, s. 84ff).

De tyske autoriteters positive holdning har næppe været uden betydning for, at Jenny Kammersgaard i 1938 svømmede mod syd. Østersøsvømningen Gedser-Warnemünde på $110 \mathrm{~km} \mathrm{i}$ 40 1/2 time den 27.-29. juli 1938 gav igen genlyd også uden for Danmark og ikke mindst i Tyskland. Symbolsk var det en stærk gestus, der bandt de to nationer nærmest fysisk sammen gennem 40 timers svømmetag. Ud fra en nazistisk tankegang kunne denne handling symbolisere fællesskabet mellem de to "nordisk-germanske« folk.

Igen modtog Kammersgaard et telegram "fra Berchtesgaden med en lykønskning fra Adolf Hitler«. Det tyske nazistpartis blad Völkischer Beobachter skrev, at "Jenny Kammersgaard har slået alle verdensrekorder i distancesvømning, hvilket er ekstra beundringsværdigt, eftersom strømforholdene på strækningen var meget vanskelige. Den danske svømmerske har dermed vundet en sejr for sit land og sin sport, som vækker opsigt over hele verden. Sejren er så meget mere bemærkelsesværdig, som Jenny Kammersgaard efter de 29 timers svømning stadig disponerede over en kraftreserve, der kunne have gjort hende $\mathrm{i}$ stand til at opholde sig $\mathrm{i}$ vandet $\mathrm{i}$ endnu flere timer. « ${ }^{21}$ I Berlin gentog historien fra 1937 sig. Svømmestjernen var indbudt af redaktør Utrecht fra Berliner Illustrierte Zeitung. Hun blev modtaget af en sværm af tilskuere, 
journalister og fotografer, talte i tysk radio og blev tonefilmet. Rigssportsføreren mødte Jenny Kammersgaard i Rigsakademiet for legemsøvelser, hvor han hyldede hende, hun gav en præstationssvømning for 2.000 tilskuere, og Tschammer kørte hende i triumftog i sin bil.

\section{FRA OLYMPISKE LEGE TIL KRIG}

Også i tiden efter De Olympiske Lege blev budskabet om den vitale og sportsglade nation udbredt. Det foregik gennem Leni Riefenstahls æstetiske og teknisk nyskabende filmværk Olympia om Berlinlegene, der havde premiere i Tyskland i 1938 på førerens fødselsdag. Her blev der udbredt et effektivt propagandabudskab om Tyskland som en fredsskabende nation med accept af den olympiske multikulturalisme og med Hitler som en landsfader, der fremstod menneskelig og engageret i den moderne konkurrencesport, som han dybest set foragtede, fordi den i princippet gav alle racer lige adgang til at vinde.

Den danske kong Christian X var til stede ved filmpremieren i København. I den anledning skrev Berlingske Tidende:

"Det er stort og herligt at have vaeret med til disse uger, da alverdens idrcet holdt mønstring og uden mislyd kcempede for idrcettens højeste are... 'Der Führer' har voeret et af de taknemmeligste kameraobjekter, og man kommer meget taet ind på hans loge $i$ øjeblikke, der afslører hans intense spaending, hans nervøsitet, hans hjerteangst - da han uafbrudt gnider sine knce - og hans gåen op $i$ landsmandenes kamp for førstepladserne. Så intimt filmes sjceldent en diktator» (Meidell, 2005, s. 160).

Der kan ikke spores nogen kritik af IOC's virke fra Danmarks Olympiske Komité eller fra det danske medlem af IOC, prins Axel. Den Interna- tionale Olympiske Komité (IOC) havde vist sig yderst velvillig over for Tyskland. IOC kunne have omgjort sin beslutning om at give legene til Berlin med henvisning til, at de ny magthavere i Berlin ikke levede op til forudsætningerne for den oprindelige udtagelse bl.a. ved at ekskludere et stort antal jødiske idrætsfolk fra den tyske OL-trup, men valgte at vende det blinde øje til (Bellers, 1986, passim). I det hele taget viste det sig, at IOC fandt det meget nemmere at samarbejde med et centraliseret styre, der kanaliserede store ressourcer over i eliteidrætten end med vestlige demokratier, der betragtede idræt som et udmærket kulturfænomen, men uden de statslige satsninger. IOC's holdning viste sig ved tildelingen af Sommer-OL i 1940 til Tokyo og Vinter-OL til Sapporo til trods for, at Japan førte krig i Manchuriet og siden 1910 havde besat Korea. Dog tildeltes OL 1944 til London, hvilket dog først blev en realitet i 1948.

Efter De Olympiske Lege fortsatte samarbejdet med og fascinationen af den tyske sport. Det betød, at danske og tyske sportsfolk udviklede tætte og måske varme relationer til hinanden, der kunne vare ved ind $\mathrm{i}$ besættelsens idrætssamkvem. I de nordiske lande gik det ikke upåagtet hen, at Tyskland 1930'erne nåede europæisk eliteklasse $\mathrm{i}$ fodbold og i boksning og var toneangivende i motorcykelløb og hastighedsflyvning samt var stærkt placeret inden for banecyklingen ikke mindst gennem W. Arend og W. Rütt. Inden for motorsporten var bilfirmaerne Mercedes-Benz og Auto-Union fra 1934 til1939 dominerende på de europæiske baner. Det samme gjaldt inden for ridesporten, hvor tyskerne tog alle guldmedaljer ved OL i 1936. Racerkøreren Bernd Rosemeyer blev fra 1936 til 1938 et symbol på den tyske sports overtag på væddeløbsbanerne. Han slog flere verdensrekorder i 
hastighedskørsel, men blev dræbt under et rekordforsøg i januar 1938 (Nordisk Familjeboks Sportlexikon, 1946, s. 109ff).

Den tyske filmindustri udviklede en hel kult om kombinationen af »teknik, motorsportsbegejstring og sportslig heltedyrkelse«, og som den tyske filolog og pædagog Victor Klemperer har vist, var det frem for alt motorsportens maskuline repræsentanter, der omkring midten af 30'erne indtog scenen som den nazistiske sports stjerner. Efter Bernd Rosemeyers død i 1938 opnåede han ifølge sprogforskeren Victor Klemperer i en periode kultstatus $i$ »folkefantasien « på linje med den nazistiske martyr Horst Wessel. I løbet af 1938 til 1940 udkom film som »Deutsche Rennwagen in Front", "Jungens, Männer und Motoren ", "Sieg auf der ganzen Linie“, " Jugend und Motor", "Deutscher Kraftfahrsport voran" og "Männer in Leder“. Den sidste film nåede først frem i biograferne i foråret 1940, og på dette tidspunkt var sløret mellem sport og krig faldet bort. Filmen sluttede med en appel: "Mænd i læder. I fredstid kæmper de for Stortysklands internationale ære. Nu er der krig. Føreren kalder også på disse motorsportens mænd, der er prøvede i kamp. Styrthjelmen byttes med stålhjelmen « (Teichler, 1991, s. 288ff).

Det tætte samarbejde mellem tysk og dansk sport fortsatte efter OL i Berlin. Her skal blot gives et par eksempler. ${ }^{22}$ Det tre dages etape landevejsløb Berlin-København bandt de to nationer Danmark og Tyskland mentalt og geografisk sammen. Løbet var indstiftet af Dansk Bicycle Club, og i samarbejde med Deutcher Radfahrer-Verband og Berlingske Tidende blev det afholdt i 1937, 1938 og 1939, hvor Tyskland alle gange vandt over de to øvrige nationer, Danmark og Sverige, i »landskampen«. Leder af Ordupbanen og Vinterbanen Jørgen Beyerholm fra
Dansk Bicycle-Club kunne fortælle, at de tyske sejrherrer i 1937 kunne hjemføre »en af den tyske rigssportsminister Hans Tschammer udsat vase i Meissner-porcelæn « (Andersen \& BudtzJørgensen, 1945 bind I, s. 115; Beyerholm, 1941, s. 249). ${ }^{23}$

I fodbold var Danmark gennem 1930'rne mere orienteret mod Tyskland end mod England. Tyskland var en vigtig sportslig modstander for Danmark med otte fodboldlandskampe frem til 1939, om end ikke så vigtig som de nordiske lande og Holland (12 kampe), men mere end England (5) (Andersen \& Budtz-Jørgensen, 1945 bind II, s. 522). Inden for fodbolden havde tyskerne krammet på det danske landshold. Tyskerne tilføjede Danmark et traumatisk nederlag på 8-0 til de konditionsstærke tyske spillere på Hermann Göring Stadion i Breslau den 16. maj 1937.

\section{KRIG OG KONTINUITET}

Ved krigsudbruddet beordrede den tyske rigssportsfører den tyske idræt til at fortsætte som hidtil, da den var en uundværlig del af den mandlige ungdoms forberedelse til at føre krig. Den tyske udenrigsminister, Joachim von Ribbentrop, indenrigsministeriet og rigssportsfører Tschammer ønskede, at Tyskland skulle konkurrere med neutrale lande så ofte som muligt.

At der nu igen var indledt en storkrig i Europa, fik ikke DIFs forretningsudvalg til at ryste på hånden. På et bestyrelsesmøde ${ }^{24}$ den 23. oktober 1939 slog Holten Castenschiold fast, at Danmark var neutralt og stod i et venskabeligt forhold til Tyskland. Der var derfor ingen grund til ikke at fastholde aftalerne om landskampe, for Tyskland var "meget sensibelt over for sligt» og fulgte «nøje vor optræden«. Kun vægtige grunde kunne »få os til at bryde aftalerne«. Ca- 




For den tyske interviewer var det glædeligt, at hagekorsbanneret (t.v.) havde en prominent placering i Bukhs gymnastiksal (Kopenhagener Soldatenzeitschrift, 20/7, 1941).

stenschiold aftalte med Krigsministeriet, at de mange indkaldte værnepligtige kunne få orlov til stævner i indland og navnlig i udland.

DIFs beslutning medførte, at Danmark blev den eneste nation blandt ikke krigsførende lande i Norden og Vesteuropa, der ikke boykottede Tyskland fra krigens begyndelse i september 1939 til 9. april 1940. Herved fik Danmark optimale muligheder for at møde de dygtige tyske sportsfolk. Danmark rykkede fra i perioden 1933 indtil 1939 slet ikke at have figureret på den tyske top fem liste over landskampmodstandere til i løbet af 1939 at rykke ind på en 4. plads med 10 landskampe, kun overhalet af Italien (14), Sverige (15) og Ungarn (16). De andre lande, der spillede mod Tyskland efter krigsudbruddet frem til 9. april 1940, var aksemagterne Ungarn, Italien, Jugoslavien, Slovakiet, Bulgarien og Rumænien samt det tysk okkuperede pro- tektorat Böhmen und Mähren (Teichler, 1991, s. $118 \& 276)$.

Tyskerne forsøgte ikke at skjule, at de følte sig hårdt ramt af den internationale sportsboykot i det første krigsår. I det nazistiske sportsblad NS-Sport var der både vrede og trusler mod de formastelige svenskere, der indtil Anden Verdenskrigs udbrud havde spillet 15 landskampe med tyskerne, men herefter sagde stop.

De danske hold tabte så ofte, at det kun kunne bekræfte de nazistiske idrætsautoriteter i deres følelse af overlegenhed. Danmark tabte en landskamp den 8. oktober $1939 \mathrm{i}$ håndbold $\mathrm{i}$ Leipzig, den 2. december 1939 i boksning i Berlin, den 7. januar 1940 i brydning i København og den 23. februar 1940 i tennis i København.

Den 2. marts 1940 mødtes repræsentanter for Danmark, Norge og Sverige i Oslo for at diskutere den internationale situation. De norske og svenske repræsentanter kunne meddele, at de havde stoppet al idrætsligt samarbejde med krigsførende lande. De andre nordiske repræsentanter undlod dog at kritisere den danske særstilling ved at slå fast, at de enkelte nationalforbunds situation var forskellig, og at man derfor ikke ville træffe nogen fælles beslutning (Holmäng, 1988, s. 180). Danmark var altså fortsat det eneste af de tre nordiske lande, der opretholdt samarbejdet med den nation, der var i gang med at sætte verden i brand. Som følge af denne linje havde bokse- og fægteforbundet planlagt landskampe med nationen, som den 9 . april 1940 skulle blive besættelsesmagt i Danmark.

\section{KONKLUSION}

Alt i alt lykkedes det for det nazistiske styre gennem 1930'erne og frem til 9. april 1940 at skabe en fascination af den tyske idræt hos danske idrætsudøvere og -ledere gennem satsning 
på et massivt, generøst og iscenesat samkvem. Herigennem var der i Danmark før besættelsen skabt stærke positive erfaringer med tysk-dansk idræt både på det personlige og det organisatoriske plan. Denne tætte kontakt og goodwill over for tysk sport kan ikke have undgået at gøde jordbunden for det omfattende idrætssamkvem, som kom i gang under besættelsen.

Efter den nazistiske magtovertagelse i Tyskland i 1933 udviklede den danske idræt en stærk fascination af Det tredje Riges oprustning på idrætsfronten. Ved De Olympiske Lege i Berlin i 1936 troppede stort set hele den officielle danske idræt op og meldte tilbage om tyskernes imponerende sejrsrække og fantastiske evne til at skabe fællesskab og atmosfære i det hidtil mest grandiose OL. Fra tysk hold var Berlin-legene lagt an som den største enkeltbegivenhed, der kunne give udlændinge indtryk af nazisternes forsøg på at skabe nye kulturformer baseret på førerkult, kropsdyrkelse, masseoptrin og en blændende æstetisk overflade. Kun blandt kommunister, kulturradikale, arbejderidrætten, jødiske idrætskredse og i den socialdemokratiske presse kunne der spores modstand mod, at et racistisk og militaristisk regime skulle afholde lege i fredens og den mellemfolkelige forståelses navn.

En hel generation af dygtige danske idrætsudøvere og ledere blev ved OL udsat for Det tredje Riges gennemførte propaganda, hvilket ikke just har styrket det åndelige immunforsvar over for Tyskland og den tyske sport, da Danmark tre et halvt år senere blev besat. Det skal dog tages med i betragtning, at de europæiske demokratier i almindelighed og Danmark i særdeleshed gennem 1930'erne havde udvist appeasement over for Tyskland, hvorfor DIFs eftergivenhedspolitik må ses som led i en større international politisk strømning. Også i spørgsmålet om boy- kot af OL i Berlin fulgte den danske debat de traditionelle skillelinjer mellem venstre og højre i europæisk politik, om end Danmark nok må siges, at være et af de lande, hvor en boykot lige fra start måtte anses for urealistisk på grund af regeringspartiernes pragmatiske linje. ${ }^{25}$

Den danske idræts internationalt set særlige position i forhold til Tyskland var især påvirket af Danmarks lidenhed som nationalstat samt dets grænseflader direkte til Tyskland og dermed sårbarhed i forhold til den stadigt mere aggressive og militaristiske nabo mod syd. I den nazistiske mytologi var danskerne et udpræget racerent folk, som delte den storgermansk/nordiske kultur med tyskerne og de andre nordiske broderlande. Danmark fik derfor en særstatus i den tyske idrætspolitik, der også byggede på gymnastikken som en særlig kontinental æstetisk og sundhedsorienteret kropskultur i modsætning til den angelsaksiske konkurrencesport med dens universalistiske principper. Danmarks geografiske beliggenhed klos op af Tyskland gav også anledning til en særlig intim idrætsudveksling, som det sås i etapeløbet København-Berlin.

Et andet eksempel på denne sammenkædning af den tyske og den danske geografi gennem idrætsudøvernes kroppe, var Jenny Kammersgaard, der i 1937 og 1938 maritimt bandt de to nationer sammen gennem sine langdistancesvømninger. I 1930'ernes anden halvdel gjorde det nazistiske regime meget for at trække danske sportsfolk til sig. Der var derfor tale om en tradition for gode bekendtskaber mellem danske og tyske idrætsfolk, der fortsatte ind i 2 . verdenskrig. På trods af DIFs relativt store politiske råderum i tiden fra Anden Verdenskrigs udbrud til besættelsen af Danmark 9. april 1940 fortsatte Danmark nemlig som det eneste ikke krigsførende vesteuropæiske land med at have idrætssamkvem med Tyskland, hvorved Danmarks 
sportslige samkvem med Nazityskland øgedes markant. Med al sandsynlighed medvirkede 1930'rnes varme og intense forhold til tysk til, at der i dansk idræt under besættelsen var villighed til og sågar entusiasme over for at dyrke sport med besættelsesmagten (Bonde, 2006, s. 79ff; Bonde, 2008, s. 55ff).

\section{LITTERATUR}

Andersen, A. L. \& Budtz-Jørgensen, J. (Red). (1945) Dansk Sportsleksikon, Standard Forlaget, København

Beck, P. J. (1999) Scoring for Britain - International Football and International Politics, London.

Bellers, J. (1986) Die Olympischen Spiele von 1936 im Spiegel der ausländischen Presse, kildeudgivelse, LIT-Verlag, Münster.

Beyerholm, J. (1941) Dansk Bicycle Clubs Historie - Strejflys over dansk Cyklesport - 1881. 1941, København

Bonde, H. (2006) Fodbold med fjenden - dansk idrcet under hagekorset, Syddansk Universitetsforlag, Odense.

Bonde, H. (2008) Oprøret i Parken-Dansk idrcet under hagekorsets tegn, Syddansk Universitetsforlag, Odense.

Ehn, B. (1993). Kropp och Känsla. I B. Ehn ,J. Frykman \& O. Löfgren, Försvenskningen av Sverige : det nationellas förvandlingar.(s.204233). Stockholm: Natur \& kultur.
Hansen, J. (1993) Hellere en Sild uden Rogn end en Akilles, hvis Hjerne sidder i hans Albuer! De olympiske lege i Berlin 1936 og diskussionen herom i Danmark, i Idrcetshistorisk årbog 1993. s. 119-139.

Havemann, N. (2005) Fussball unterm Hakenkreutz - Der FdB zwischen Sport, Politik und Kommerz, Frankfurt/Main.

Holmäng, P.O. (1988) Idrott och Utrikespolitik, Den svenska Idrottsrörelsens internationella förbindelser 1919-45, Göteborg.

Huggins, M. \& Williams, J. (2006) Sport and the English 1918-1939, New York.

Idorn, J. (1971) Dansk Idraets-Forbund's Jubiloeumsskrift 1896-1971, København.

Kammersgaard, J. (1937) Svømmeturen, København, kap. 9, Jenny Kammersgaards egen beretning, s. $84 \mathrm{ff}$.

Krarup, H. og Møller L. (1989) Da sporten var ung - en billedkavalkade fra 1920-1945, København.

Kristensen, P. (1996) De olympiske: biografi af danske OL-deltagere: 1896-1996, Danmarks Idræts-Forbund, København.

Krüger, A. (1987) Sieg Heil to the Most Glorious Era of German Sport - Continuity and Change in the Modern German Sports Movement. I The International Journal of the History of Sport, vol. 4, 1987, (s.5-21). 
Krüger, A. \& Murray W. (eds.) (2003) The Nazi Olympics: Sport, Politics, and Appeasement in the 1930s, Illinois.

Mangan, J.A. (red.) (1995) Tribal Identities, Nationalism, Europe and Sport, London.

Meidell, B. (2005) Slået med beundring, København

Nordisk Familjeboks Sportlexikon (1938 - 1949), Stockholm.

Pfister, G. \& Niewerth T. (1999) Jewish Women in Gymnastics and Sport in Germany, I: Journal of Sport History. 1999, s. 287-326.

Steinhöfer, D. (1973) Hans von Tschammer und Osten, Berlin.

Teichler, H.J. (1991) Internationale Sportpolitik im Dritten Reich, Verlag Karl Hofmann Schorndorf.

Thamer, H.U. (1986) Verführung und Gewalt, Berlin.

Thelmark, S. (1999) Jødisk Idrcetsforening Hakoah København, speciale Syddansk Universitet (upubl.), Institut for Idræt og Biomekanik, Odense.

Trangbæk, E. (1995) Dansk Idraetsliv, bind I og II, Danmarks Idræts-Forbund, København.

\section{NOTER}

1. Den tyske rigssportsminister i juli 1939

2. Op.cit., s. 118

3. Kildematerialet til denne artikel udgøres af Udenrigsministeriets arkiver og DIFs arkiver på Rigsarkivet, arkivet på Gymnastikhøjskolen i Ollerup, Det Kongelige Biblioteks småtryksafdeling samt diverse idrætstidsskrifter.

4. Formandsskiftet foregik den 29-30.7.1933.

5. Hele det følgende afsnit om rigssportsføreren bygger, når intet andet er nævnt, på Steinhöfers biografi. Steinhöfers lettere apologetiske biografi er blevet søgt afbalanceret med Hans Joachim Teichlers (1991) mere faghistorisk velfunderede monografi om Det tredje Riges idrætspolitik.

6. Fyns Venstreblad, 27.3.1935.

7. Idrætsbladet 27.2.1936, s. 24.

8. Idrætsbladet 4.8.1936, nr. 32, s. 4.

9. Udenrigsministeriets Arkiv, $45 \mathrm{~N}$ 8a Olympiske Lege, pak ke III fra 22/12-35 til 31/12-55, brev fra Christmas Møller til kammerherre H.A. Bernhoft 29.12.1935.

10. Jydsk Idræts Blad, 9.12.1935.

11. Jvf. grøn scrapbog, Olleruparkivet (forkortet OA), udateret avisartikel, s. 66

12. På trods af forskønnelsen af den politiske virkelighed kunne en dansk journalist som Evald Andersen godt se gennem facaden, jvf. hans dækning af OL i Nationaltidende.

13. Interview med H. Lykke, der blev rost for sine fletninger, for »det var jo så typisk arisk«. Interview med G. Fabricius.

14. Interview med H. Lykke fra Bukhs elitehold 1936.

15. Jvf. Berlingske Tidende, 6/8. Artiklen bragtes også i DI, nr. 33, 15.8.1936, s. 394ff.

16. Ifølge Ungdom og Idræt, nr. 34, 21.8.1936, s. 421.

17. Ifølge Jensen, A., Sorø Amtstidende, udateret, grøn scrapbog, OA, s. 64.

18. Udenrigsministeriets Arkiv, $45 \mathrm{~N}$ 8a Olympiske Lege, pak ke III fra 22.12.35 til 31.12.55. Indberetning af 12.2.1936.

19. D.K.G.s medlemsblad, nr. 1, okt. 1936, s.1ff.

20. Se D.K.G. - Medlemsblad for Dansk Kvinde-Gymnastikforening, nr. 2, januar 1936. Se også Ellen Paul Petersen "En samtale med Medau", D.K.G. - Medlemsblad for Dansk Kvinde-Gymnastikforening, nr. 1, november 1937, s.1f.

21. Op.cit., 11.8.1938

22. For en uddybning se Bonde, H., 2006, s.67ff.

23. Dansk Sportsleksikon 1945 I, s. 115, Idrætsbladet 25/7, 1939. Endvidere Beyerholm 1941, s. 249

24. DIF pakke 14 - bestyrelsesmøde d. 23/10 1939

25. Om andre landes reaktioner på OL i Berlin, se Krüger \& Murray (eds.) 2003, s. 28. 